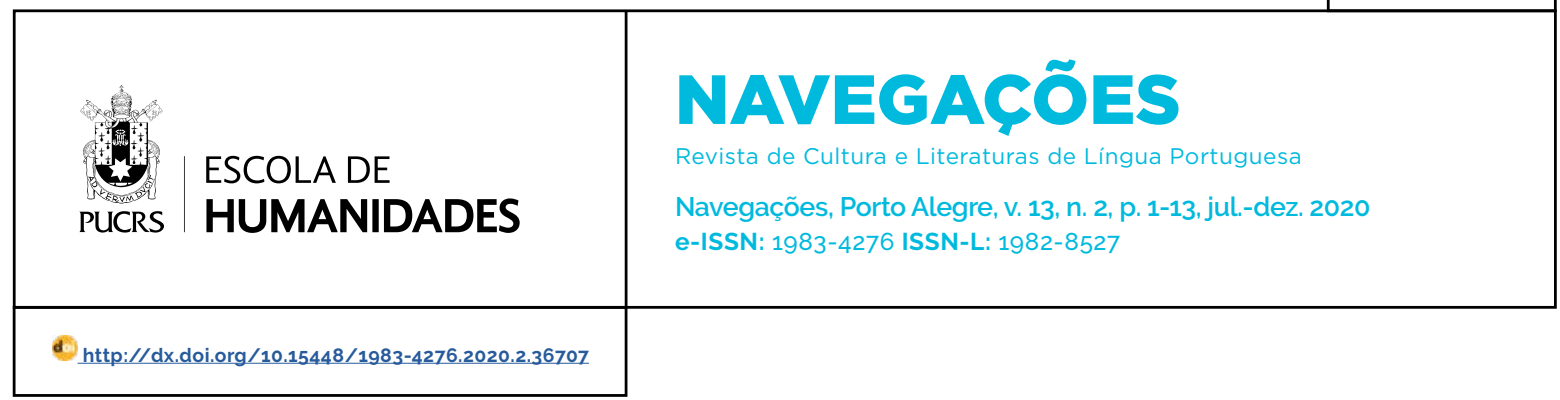

ENSAIOS

\title{
A transição histórica em 0 pintor de retratos de Luiz Antonio de Assis Brasil
}

Historical transition in The portrait painter by Luiz Antonio de Assis Brasil

\section{Renata Fonseca Wolff ${ }^{1}$}

orcid.org/0000-0003-4839-4398

renata.wolff@edu.pucrs.br

Recebido em: 9/1/2020.

Aprovado em: $2 / 6 / 2020$

Publicado em: 25/2/2021.

\section{(c) (i)}

Artigo está licenciado sob forma de uma licença Creative Commons Atribuição 4.0 Internacional.
Resumo: O presente artigo tem como objetivo investigar as marcas de historicidade no romance $O$ pintor de retratos, do escritor Luiz Antonio de Assis Brasil, e seus significados. Examina-se a forma como esses marcadores se articulam para revelar as caracteristicas do novo romance histórico, representando diversas expressões de transição histórica na passagem do Velho para o Novo Mundo e do século XIX para o século XX, especificamente quanto às mudanças trazidas pela Segunda Revolução Industrial. Sobreposta a esse contexto, acompanha-se a transição pessoal do protagonista, Sandro Lanari, em sua movimentação cronológica, geográfica e psicológica rumo à maturidade. Por fim, aprecia-se como o comentário histórico espelha também, de forma metaficcional, a transição do romance enquanto gênero e da obra literária de seu autor.

Palavras-chave: O pintor de retratos. Luiz Antonio de Assis Brasil. Novo romance histórico.

Abstract: This paper aims to explore the historical markers in the novel The portrait painter, by the writer Luiz Antonio de Assis Brasil, and their significance. We examine how such markers are organized in such a manner as to reveal the characteristics of the new historical novel. They do so by representing various expressions of historical transition from the Old to the New World and from the 19 th to the 20th century, specifically the changes brought on by the Second Industrial Revolution. Overlapping this context, we move alongside protagonist Sandro Lanari in his personal transition as he journeys chronologically, geographically and psychologically towards maturity. Finally, we appreciate how the historical commentary also mirrors, in metafictional fashion, the transition of the novel as genre and of the author's literary body of work.

Keywords: The portrait painter. Luiz Antonio de Assis Brasil. New historical novel.

\section{Introdução}

O pintor de retratos, de Luiz Antonio de Assis Brasil, localiza seus eventos em finais do século XIX, isto é, estabelece desde logo a presença do passado na narrativa. Essa presença se manifesta em aspectos os mais diversos da obra, e engendra circunstâncias determinantes para os conflitos pessoais de seu protagonista; as marcas da historicidade envolvem-no e informam o enredo e seu contexto (dir-se-ia pano de fundo).

O que o presente artigo se propõe a fazer é perquirir desses marcadores e de sua organização, e averiguar a categorização de $O$ pintor de retratos como novo romance histórico. Para tanto, nos utilizamos do método de pesquisa bibliográfica de autoras e autores que estudaram a relação entre literatura e história e as características do gênero, bem como a obra em 
si, e um registro de entrevista do autor.

Esperamos, assim, contribuir com o fornecimento de elementos adicionais para o aprofundamento da leitura e apreensão desse romance, uma das melhores expressões da produção literária de Luiz Antonio de Assis Brasil.

\section{0 pintor de retratos: enredo sumarizado}

O pintor de retratos é a história do italiano Sandro Lanari, descendente de gerações de pintores sem notoriedade e que, na adolescência, aprende o ofício com o pai.

Na primeira parte do romance, Sandro deixa sua cidade natal, Ancona, porto do Adriático, a fim de estudar pintura em Paris. Na capital francesa, Sandro depara-se com a fama não de pintores, mas do fotógrafo Nadar, que registra personalidades da época com maestria, especialmente a atriz Sarah Bernhardt, exposta na vitrine do estúdio e que causa impacto no pintor.

A estada é uma sucessão de desencantos para Sandro: com seu mentor, com a arte moderna que não compreende, com dificuldades financeiras e uma paixão malfadada por uma costureira. Ele faz-se fotografar pelo próprio Nadar, e detesta de tal forma o resultado que destrói a imagem ao fogo.

Ao saber do Brasil, acaba decidindo-se por emigrar, e sua chegada a Porto Alegre inicia a segunda parte do romance. Sandro hospeda-se em uma pensão e observa os curiosos hábitos da província. Entre escassas encomendas - pois também na nova pátria afirmam-se os fotógrafos e não os pintores como ele - e experiências insólitas, finalmente um advogado acolhe Sandro como hóspede a fim de que, a médio prazo, capture toda a familia em retrato.

Na casa do advogado, Sandro inicia a pintura encomendada e constantemente rumina sobre a superioridade do retrato pintado em relação à fotografia. E, o que é mais relevante, inicia um romance secreto com a filha do cliente, Violeta.

Descoberto, Sandro foge para Rio Pardo, onde tem princípio a terceira parte do romance. Lá, o pintor começa a ser chamado para retratar pessoas falecidas em estâncias. Bem-sucedido, compra uma charrete, um cavalo, contrata um indio guarani como cocheiro, improvisa materiais e torna-se retratista ambulante.

Em meio às andanças de Sandro e seu cocheiro pelo pampa, eclode a Revolução de 1893 (dita "da degola"). O protagonista sequer toma conhecimento da disputa e não compreende seus matizes políticos. Ainda assim, vê-se sob o cerco de uma unidade legalista e consente em segui-la e tornar-se seu fotógrafo oficial.

Nesse cenário, e em meio à saudade de Violeta e às angústias existenciais de Sandro (ainda era o "eu" conhecido, pintor, ou era agora este "outro", fotógrafo?), sobrevém uma experiência definitiva: ele registra, nos momentos posteriores a uma batalha, a ação do degolador Adão Latorre e o último olhar do degolado, direto para a câmera.

Sandro revela a imagem e, impressionado, denomina-a "Foto do Destino". Acredita que ela é o sinal de sua arte e que vale mais do que todas as fotos de Nadar. Guarda-a para si e, abalado, obtém autorização para partir, deixando o cocheiro com a unidade, em semiescravidão.

Na quarta parte do romance, Sandro Lanari retorna à Capital. Procura Violeta (seu pai, o advogado, falecera na revolução) e, mesmo sem a paixão da juventude, casam-se. Em poucos anos, têm quatro filhas. Embora o matrimônio não seja infeliz, tampouco salva-se de silêncios, distanciamentos, olhares perdidos.

Sandro Instala um próspero ateliê de fotografia. Desenvolve suas técnicas, recebe elogios no jornal, engorda, frequenta a alta sociedade, contribui à filantropia. Ao mesmo tempo, desconcerta-se ao ver em uma vitrine um retrato a óleo, feito por um jovem pintor, com quem discute; à noite, inquieto, consola-se pensando que a "Foto do Destino" é sua segurança, algo que ninguém fizera e jamais faria.

Ante a notícia da morte do pai, Sandro embarca rumo à Europa. Faz um desvio a Paris, e depois Marselha, em busca de Nadar. Encontra-o velho e rabugento. Sandro pede que o fotografe e, revelada a imagem, Nadar declara-o um tolo e diz que pode levar a foto de graça. Indignado, Sandro afinal mostra a "Foto do Destino", como prova de sua arte. Como resultado, é expulso por um Nadar enfurecido, o qual declara, definitivo, que aquilo é uma barbárie sem alma. 
Na última cena de Sandro, ele está no trem de Marselha à Itália. Ainda observa a "Foto do Destino" e convence-se de seu valor artístico. Já a fotografia de si próprio, tirada por Nadar, essa Sandro puxa do bolso, rasga metodicamente e lança em fragmentos pela janela. Pensa em Violeta e nas filhas e pega no sono: Sandro Lanari está, enfim, livre de Nadar.

\section{Transições históricas, pessoais e Literárias: o novo romance histórico}

Uma vez delineados os eventos, personagens e conflitos da obra, caberia a pergunta: O pintor de retratos é um romance histórico?

A primeira reflexão que o questionamento engendra é melhor expressa na lição de Carlos Alexandre Baumgarten (2001, p. 75), quando o autor esclarece que "todo romance, como produto de um ato de escrita, é sempre histórico, porquanto revelador de, pelo menos, um tempo a que poderíamos chamar de tempo da escrita ou da produção do texto", com a subsequente ressalva de que, no âmbito dos estudos literários, o que se convencionou denominar de romance histórico "corresponde àquelas experiências que têm por objetivo explícito a intenção de promover uma apropriação de fatos históricos definidores de uma fase da história e de determinada comunidade humana", tendo surgido no século XIX, com Walter Scott (BAUMGARTEN, 2001, p. 75).

Nessa visão, parece-nos evidente a historicidade presente na narrativa em estudo, ou seja, os fatos históricos que, em maior ou menor grau, determinam eventos ficcionais (como a Revolução Federalista de 1893, que influi diretamente sobre o destino de Sandro Lanari ao transformá-lo em fotógrafo de batalha no pampa rio-grandense) ou, no mínimo, colorem-nos lé o caso da eclosão dos movimentos impressionistas na arte da França da belle époque, cuja modernidade desconcerta Sandro durante seu periodo parisiense).

Mais: as marcas da história em O pintor de retratos encontram-se até mesmo em seus elementos extratextuais, desde seu título e sua capa - ao menos a da edição que serve de base a este trabalho, a 6. ${ }^{\mathrm{a}}$, de 2002 -, adornada pela imagem de Sarah Bernhardt registrada por Nadar por volta de 1864, o mesmo retrato que atormentou o protagonista. Nesse sentido, Hugo Aust nota que os romances históricos enviam sinais do tempo, tais como datas, nomes, detalhes e documentos que expressam "diferença e distância temporal, mesmo quando não 'transferem' o leitor para o passado e sim para a ficção" (AUST, 2016, p. 10).

No texto, esses sinais do tempo encontram-se esparsos em qualquer lugar; mas é típico encontrá-los com frequência já no título, no subtítulo ou na designação do gênero, na capa do livro (texto de orelha, ilustrações nas capas externa e interna poderiam ser mencionadas aqui, embora raramente provenham do autor), no prefácio e no início do romance (AUST, 2016, p. 10).

Sendo inegável o caráter histórico da narrativa, estar-se-ia diante de um romance histórico clássico? Retornando à lição de Baumgarten (2002, p. 76), esse identifica algumas marcas essenciais do romance histórico sul-rio-grandense tal como concebido em sua origem, extraídas da paradigmática obra O romance histórico de Georg Lukács: a) a obra traça grandes painéis históricos; b) é observada a temporalidade cronológica dos acontecimentos; c) há personagens fictícias que são utilizadas na análise dos fatos históricos; d) as personalidades históricas são apenas citadas ou integram o pano de fundo; e) os dados e detalhes históricos são fornecidos no intuito de conferir veracidade à narrativa, aspecto que torna a história incontestável; e f) o narrador em terceira pessoa simula distanciamento e imparcialidade, procedimento herdado do discurso historiográfico.

Não nos parece ser esse o caso da obra em exame. O compromisso com a história que emana das caracteristicas elencadas por Baumgarten (2002, p. 76, d'après Lukács) é secundário, quando não ausente, em o pintor de retratos; não se constata a ambição de construir abrangentes panoramas, de enfileirar cronologicamente nomes, datas e eventos como suporte de veracidade, de proceder a distanciadas e imparciais apreciações do contexto histórico. Pelo contrário - quando manifestados explicitamente, os personagens e descaminhos históricos servem à narrativa ficcional, mais especificamente aos conflitos, à jornada 
particular e à moldagem da psique de seu protagonista, e a esse processo de construção permanecem submetidos. Aqui nos aproximamos do que Lukács apontou, com relação à obra de Conrad Ferdinand Meyer, como sendo "a preponderância que o elemento psicológico-moral tem sobre os motivos histórico-políticos" (LUKÁCS, 2011, p. 276).

Embora a distinção de gênero não seja o objeto do presente trabalho, até mesmo a classificação da obra como romance, na acepção utilizada na classificação lusófona, é, nesses parâmetros, questionável: ela se apresenta mais enxuta, organizada ao redor de um personagem (com breves incursões na interioridade dos outros mais próximos a ele, como Violeta) e de um conflito (interno, de Sandro Lanari, com ramificações externas), sendo afeita à novela - na precisa concisão de Nubia Jacques Hanciau (2006, p. 55), O pintor de retratos é novela para alguns e romance para outros.

De toda sorte, o que releva apontar é que, ante as peculiaridades de que se encontra centrada em personagens comuns, com ficcionalização dos personagens históricos, e de que contempla a reescritura deliberada da história de forma a servir à narrativa de ficção, no que interessa para a psicologia da personagem, está-se diante do que se veio a denominar novo romance histórico.

Passa-se, pois, a explicitar como os elementos desse gênero se manifestam em O pintor de retratos. Partindo da classificação de Seymour Menton (1993, p. 42-45), constatam-se caracteristicas do novo romance histórico, conforme elencadas por esse autor, e que se passam a identificar.

a) A reprodução mimética de certo periodo histórico é submetida à apresentação de algumas ideias filosóficas, notadamente, no caso de $O$ pintor de retratos, o caráter cíclico e ao mesmo tempo imprevisivel da história, cuja verdade é impossivel conhecer (MENTON, 1993, p. 42). Isso se reflete, entre outros aspectos, na maneira como é apresentada a Revolução Federalista, pelo desentendimento perplexo de Sandro - "Que revolução?", indaga ao ser surpreendido pela movimentação das tropas no pampa (ASSIS BRASIL, 2002, p. 119) -, estendido ao narrador em terceira pessoa: "No Rio Grande do Sul as revoluções ocorriam sem que as causas ficassem claras. Houve muitas revoluções" (ASSIS BRASIL, 2002, p. 120); "Para ele, a revolução era um embate de lenços brancos contra vermelhos" (ASSIS BRASIL, 2002, p. 126). Além disso, a própria jornada pessoal de Sandro, na busca pela afirmação artística, revela-se ciclica: definida por duas visitas muito diferentes ao fotógrafo Nadar, separadas por décadas, e marcada pela passagem de aprendiz de pintor e diletante admirador da fotografia a artista consagrado, chegando a deparar-se, na idade madura, com um retratista iniciante que, como ele, aprendera o oficio na Itália, encontro que o impacienta e abala em razão das inovações interpretativas do rapaz, e acaba em um "mutismo hostil" (ASSIS BRASIL, 2002, p. 169).

b) A história é conscientemente distorcida mediante omissões, exageros e anacronismos (MENTON, 1993, p. 43). Os hábitos dos cidadãos porto-alegrenses, em especial logo após a chegada de Sandro em terras gaúchas, são caricaturizados e, assim, enfatizam o contraste com a civilização europeia. Apenas como um exemplo, os hóspedes da Pensão Itália (repare-se o magistral toque de ironia no nome do estabelecimento) alimentam-se em silêncio, mastigam de boca aberta, limpam-se nas mangas das camisas (pois não há guardanapos), e cospem nas escarradeiras de faiança azul "segundo a educação ou a pontaria" (ASSIS BRASIL, 2002, p. 52). A própria cidade, vista do alto, transforma-se "num leque aberto e roto em vários lugares" (ASSIS BRASIL, 2002, p. 54), desola-se a partir do meio-dia com os "hábitos da preguiça" (ASSIS BRASIL, 2002, p. 54), e as águas do rio formam uma "chapa incandescente, refletindo o fulgor do sol" (ASSIS BRASIL, 2002, p. 55):

Em Ancona ele também contemplava paisagens aquáticas e bastante pictóricas: lá, era o Adriático, povoado por lendas de heróis descabelados e furibundos, varridos pelo colérico ribombar dos canhões, itinerário de bojudas galeras venezianas e bizantinas desde épocas sem memória, habitação dos deuses e cenário de batalhas decisivas para a Humanidade.

Aqui, era o Guaiba.

E ele, Sandro, era um artista que trazia nas costas a Europa e seus séculos de civilização (ASSIS BRASIL, 2002, p. 55). 
Registre-se que não se duvida da correspondência entre tais descrições e o cenário da Porto Alegre de fins do século XIX; atenta-se, apenas, a que a seleção desses ângulos de observação constitui, em si, um exagero dos traços menos desenvolvidos de uma localidade e de uma época, com a finalidade de compará-la ao refinamento de civilizações mais consolidadas, dentro da perspectiva eurocêntrica do protagonista.

Quanto às omissões, elas se traduzem em frases concisas que encerram profundo significado histórico e humano. O melhor uso desse recurso está em uma das primeiras observações de Sandro Lanari em Porto Alegre: "Seu primeiro espanto foi pela quantidade de negros nas ruas. Pensou que fossem maometanos. Mais tarde saberia a verdade" (ASSIS BRASIL, 2002, p. 51). Veja-se o logro da elipse; basta a declaração de que "mais tarde saberia a verdade" - e para uma leitora minimamente familiarizada com a barbárie da escravatura infligida ao povo africano é de todo desnecessário avançar na especificação da cruel e aterradora "verdade" aludida - para trazer à narrativa, em um único flash discursivo, séculos de um dos mais vis sistemas de opressão e tortura já praticados pelo ser humano contra seu semelhante, subitamente materializado diante do protagonista.

c) A utilização de um cidadão comum como protagonista, combinada com a ficcionalização das personagens históricas (MENTON, 1993, p. 43). Sandro Lanari nada tem de excepcional e desloca-se como mera testemunha, ou na melhor das hipóteses como relutante e secundário participante, dos fatos sociais e políticos do seu tempo. Por sua vez, as personalidades da época - o fotógrafo Nadar, em Paris; o então presidente do Estado, Júlio de Castilhos, que não é identificado por nome; o bispo Dom Cláudio Ponce de Leão; Adão Latorre, famoso degolador da Revolução de 1893 - têm aparições coadjuvantes e, em vários casos, são ficcionalizadas em termos exagerados e paródicos, invocando outra expressão do novo romance histórico identificado por Seymour Menton (1993, p. 44). Nadar, na velhice, arrasta os chinelos, respira mal, tem excessivas rugas e é uma "figura esmagadora" (ASSIS BRASIL, 2002, p. 174-175). Adão
Latorre - em descrição que se confronta com a aparência do degolado branco, de "rosto digno" e que "poderia ser um príncipe" (ASSIS BRASIL, 2002, p. 134), e permite entrever o etnocentrismo do observador - é um "vulto sombrio [...]. Latorre tinha o torso nu, lavado em sangue. Os cabelos empastavam-se de suor. [...] Corria uma penumbra de maldade naquela mirada" (ASSIS BRASIL, 2002, p. 134). E a Júlio de Castilhos é reservada a maior carga de paródia: descrito pelo advogado, pai de Violeta, como "bexigoso-positivista" (ASSIS BRASIL, 2002, p. 73) e "crápula-mor" (ASSIS BRASIL, 2002, p. 91), o mandatário é "baixo, inflexível, e o cabelo rapado dava-lhe um certo tom militar" (ASSIS BRASIL, 2002, p. 91), sorri com superioridade, tem manias e é retratado com as "marcas da variola" (ASSIS BRASIL, 2002, p. 93).

d) Por fim, a intertextualidade (MENTON, 1993. p. 43), presente em toques sutis e que reafirmam, de maneira a mais simbólica, a disparidade entre a cultura e a arte clássicas que conheceu na Europa (na juventude, Sandro memorizara a Eneida de Virgílio), representadas nas Metamorfoses de Ovídio e no Il Libro dell'Arte de Cenino Cenini, e a vida de retratista itinerante nas coxilhas austrais do Novo Mundo, exatamente no momento em que Sandro desfere um gesto definitivo e resignado de rejeição dos antigos sonhos em favor dos modos da pátria adotada:

Quando a tinta começasse a craquelar e o pano se desfiasse, ele já estaria morto. E tudo seria atribuido ao tempo. Tempus edax rerum, ele sabia das Metamorfoses. De resto, ninguém teria visto algo melhor aqui no Rio Grande, terra tão inculta e provisória.

E para demarcar sua nova existência, libertou-se de Il Libro dell'Arte, jogando-o num arroio de águas confusas: "Vai-te, petulante, que não tens nenhum valor nesta parte do mundo" (ASSIS BRASIL, 2002, p. 118).

Aurora Gedra Ruiz Alvarez (2011, p. 65) também percebe o descarte do manual de Cenini como um passo significativo no processo de incorporação cultural de um personagem que, desde Paris, resistia às transformações e, assim, barrava uma - ao fim e ao cabo inevitável - crise identitária: 
Compreende a personagem que tem que descobrir recursos na realidade local para o desenvolvimento de sua arte. Observa-se, também no âmbito da arte, o processo de hibridização. Por outro lado, apreende-se o etnocentrismo europeu que vê as estâncias gaúchas como uma terra selvagem, onde a cultura da Europa não frutifica (ALVAREZ, 2011, p. 70).

Nubia Jacques Hanciau enfatiza nessa contraposição entre as duas culturas uma dupla perspectiva que guia o autor na condução do personagem e da obra, "duas coordenadas, uma interna, a brasileira, e outra externa, a europeia. A genialidade do escritor também está em construir esse discurso, um olho voltado para lá, o outro para as entranhas de sua sociedade" (HANCIAU, 2006, p. 57).

Ainda, há marcas adicionais do novo romance histórico, agora considerando aquele delineado por Antônio R. Esteves (2010, p. 36-37) a partir do artigo "La nueva novela latinoamericana" de Fernando Aínsa.

Uma delas é o discurso histórico dessacralizado, desprovido de absolutismos, por vezes revestido da paródia, do burlesco e do sarcástico (ESTEVES, 2010, p. 37), visivel nos trechos anteriormente citados, na forma cética e ocasionalmente ácida como a narrativa aborda as disputas políticas, as personagens eminentes da época, o modo de vida em Porto Alegre e no Rio Grande do Sul. Acrescenta-se aí o inglório desfecho de uma luta revolucionária presenciada por Sandro:

Sandro perguntava aos soldados quem vencia, e não lhe davam importância. Tratavam de fugir dali. Não discutiam muito: em seguida se embrenhavam no mato, levando tudo o que podiam carregar. Sentado numa pedra, estava o cozinheiro, um velho gordo, cabelo à escovinha, de bombachas e alpargatas. Escarrou forte:

- Todo mundo debanda, nessa revolução de merda (ASSIS BRASIL, 2002, p. 130)

Outra, que vai no mesmo sentido, é a releitura crítica da história, afastada da historiografia oficial, buscando a multiplicidade de perspectivas e o resgate de vozes silenciadas (ESTEVES, 2010, p. 36). As passagens que retratam essa visão crítica em termos mais emblemáticos encontram-se no desavisado envolvimento de Sandro com a guerra civil gaúcha. A primeira é a que descreve os próprios contornos do embate, reduzindo-o a uma versão crua que desafia a dos livros de história, e o confronta, novamente, com o aparentemente idilico estado das coisas na Europa:

\begin{abstract}
Houve muitas revoluções. Significavam disputas de poder entre os senhores da aristocracia bovina. Na infância da República aconteceu um dos mais selvagens conflitos da História. As partes digladiavam-se nos campos sem fim. As pelejas eram travadas com fuzis, baionetas, lanças e facões, sob o comando de proprietários rurais improvisados em coronéis. Eles levavam seus servos para a luta, formando esquadrões de cavalaria. Eram esfarrapados, feios, sórdidos. Usavam chapelões com um palmo de aba. Diziam obscenidades e se embriagavam. No inverno, combatiam com os lábios gretados pelo vento Minuano, o que vem da Cordilheira dos Andes.
\end{abstract}

Como resultava caro manter os prisioneiros, matavam-nos. Esses infelizes eram organizados numa fila, e um homem cruel, chamado degolador, rasgava-lhes as carótidas com uma faca. O agonizante, entregue a si mesmo, levava as mãos à garganta, tentando estancar o fluxo de sangue. Dava alguns passos trôpegos, as pernas cediam e ele tombava. Já era um cadáver que contemplava o céu. Suas pupilas refletiam as nuvens, muito lentas. Após a agonia e a dor, instalava-se a serena beleza da morte.

Por vezes eram degolados cinquenta em um só dia. Os coronéis esqueciam-se de comunicar esses morticínios a seus superiores. E os superiores dedicavam-se à política.

Em Paris, Rodin esculpia Le baiser em mármore finissimo, e Debussy compunha o delicado l'Après-midid'un faune (ASSIS BRASIL, 2002, p. 121).

O segundo trecho a ilustrar essa característica é a despedida entre o cocheiro guarani e Sandro, quando esse é libertado pelo destacamento legalista e deixa os campos de batalha. Em cinco frases e uma cena breve encapsula-se um vislumbre não somente da condenação dos chamados indios à servitude na guerra fratricida dos brancos (e, nesse caso, do abandono perpetrado até mesmo por seu suposto amigo), mas também, por extensão, do tratamento do europeu colonizador para com os povos nativos da América:

O indio teve de ficar, pois era considerado meio escravo. Despediram-se. Sandro ofereceu-lhe dinheiro. Ele recusou e deu-lhe as costas. Sandro chamou-o, mas inútil: e não sabia o que era a esfera de remorso que se formava em sua garganta e o impedia de engolir a saliva grossa (ASSIS BRASIL, 2002, p. 136). 
O terceiro elemento reconhecido por Esteves (2010, p. 37) e verificado em O pintor de retratos é a recusa da distância épica, pelo uso do monólogo interior e de outros recursos que desvelam a subjetividade e a intimidade das personagens. Esses dispositivos perpassam a narrativa; veja-se Sandro, errante no pampa, em reflexão que mescla cronologias e vai ao âmago de seus conflitos pessoais:

Foi tomado pela inédita sensação de não ter passado nem futuro, e que o Destino, depois de encontrá-lo, esquecera-se dele. Vinham-lhe lembranças confusas, Paris, Violeta, o pai, mas pareciam figurar numa ação de fantoches que falavam uma língua desconhecida.

Sem remorso, constatou que a pintura não era forte em seu espirito, tanto que a abandonara como se nunca a tivesse praticado. Aquilo era coisa de Curzio, que o obrigara a ser pintor. Mas o que ele, Sandro, na verdade queria? Era um menino, em Ancona, e naquele tempo, o mais importante era Catalina. E fizera uma mistura tremenda. Dois homens o habitavam: aquele que pintava e o Outro, que precisava seguir a obscura vida.

- Sou eu mesmo ou sou o Outro? - perguntava ao indio.

- Acho que é o outro (ASSIS BRASIL, 2002, p. 127).

Mais um desses instantes pertence a Violeta. Depois de passar despercebida pelo marido, ele retorna à sala, onde Violeta bordava, e os dois têm um curto diálogo sobre trivialidades. Ao final da cena há um leve descortinar de um mundo de sentimentos que permanece oculto de Sandro e, até então, também da leitora.

Ele aproximou a mão, no intento de acariciar os cabelos de Violeta. Quando ela o fitou, ele retirou a mão. Disse-lhe que iria jantar. Ela não o acompanhava?

- Preciso terminar esta parte do risco. Vou demorar.

- Então está bem - disse ele.

E saiu assobiando La paloma, sem se aperceber do olhar de serena tristeza e desencanto que ela lhe lançava às costas, e que a matava de hora em hora (ASSIS BRASIL, 2002, p. 166),

O quarto e último aspecto adicional na lição de Esteves (2010, p. 37), relativo à superposição de tempos históricos diferentes, advém em parte dessas incursões na interioridade das personagens. Constata-se esse jogo de cronologias nos saltos para instantes vindouros, imaginados ou não. Já citamos aqui um exemplo, no qual Sandro prevê que já estaria morto quando sua criação em tinta e pano se desfizesse, "e tudo seria atribuido ao tempo" (ASSIS BRASIL, 2002, p. 118). Um outro, prévio, é o do protagonista, emocionado, após ver uma jovem viúva acariciar e quase beijar o retrato do marido morto, pintado por Sandro:

Enfim Sandro fizera algo de inesperado e nobre em sua miserável existência, ele, um homem perdido e enganador, ele, que sobrava no funcionamento geral do universo. Enterneceu-se com o poder de suas mãos, inaptas e terrenas, sempre à beira do desastre. Via-as, manchadas de tinta. Através do filtro líquido das lágrimas, as cores ondulavam e misturavam-se.

Velho, ele lembraria esse momento (ASSIS BRASIL, 2002, p. 108-109).

E centra-se na personagem Violeta a superposição temporal mais fulminante, a única a merecer, com o uso do presente do indicativo, a cristalização no tempo da leitura, em tom simultaneamente mórbido e sublime:

Uma vez enxergou Violeta à janela, e achou- lhe um interessante perfil. Perguntou-lhe se poderia fotografá-la.

- Se você quer.

A tarde estavam no atelier. Sandro colocou-a sentada, segurando uma sombrinha com rendas. Pediu-lhe que olhasse para a lente. Foi para detrás da câmara.

- Não se mova.

De súbito ele enfrentava um olhar que surgia, $e$ que não era o de hoje, mas o de ontem, do passado, um olhar constrangedor. Não era certo que sua mulher ainda ostentasse aquele olhar.

Ele ordenou, impaciente:

- Vire o rosto para o lado.

Ela obedeceu. E Sandro acionou o obturador

A fotografia destinou-se ao álbum com capa de veludo azul e cantoneiras em latão vermelho, igual ao que possuiam todas as familias para distração das visitas. Essa mesma foto serviria, alguns anos depois, para fazer-lhe um retrato em porcelana oval, com um fio de ouro contornando as bordas, e que pode, ainda hoje, ser visto na necrópole da Azenha, em seu túmulo.

Ela está ali, olhando para o nada (ASSIS BRASIL, 2002, p. 151-152).

Assim colocados os marcos históricos e de gênero (como novo romance histórico) em O pintor de retratos, evidencia-se que todos eles expres- 
sam transições, em diversas camadas narrativas.

Externamente, nos deslocamentos de Sandro e nas transformações que ele observa e às quais se integra, tem-se a passagem (aproximada) do século XIX ao século XX; do Velho Mundo ao Novo Mundo; da metrópole urbana à colônia provinciana; da cultura clássica europeia à cultura nascente das Américas; do Brasil imperial à República recém-proclamada; das revoltas civis ao início da consolidação política, no País e no Estado; do campo à cidade; e, com mais imediato efeito sobre sua arte, as transformações da Segunda Revolução Industrial.

Ao mesmo tempo, acompanhamos Sandro em um grande arco transicional, permeando suas dúvidas existenciais traduzidas na ansiedade relativa ao seu ofício e, por derivação desse, à sua identidade: Sandro passa da juventude à maturidade; das paixões adolescentes ao amor cômodo com Violeta; da inconformidade ao apaziguamento; do nomadismo inconsequente à morada fixa em Porto Alegre; de uma tradição artística herdada a um caminho individualmente construido. Sandro encaminha-se a aceitar-se e firmar-se como fotógrafo, arte que lhe incumbiu tanto por escolha quanto por contingências do destino.

Tais articulações em Sandro sugeririam um Künstlerrroman, não fossem, também elas, marcas do romance histórico moderno, pois espelham no plano íntimo a crise no plano social, conforme aponta Regina Zilberman (2003, p. 134-135), elencando, em sua leitura de Lukács, os traços característicos do gênero, observados em Tolstói: a escolha de periodos representativos; a tradução desses momentos de crise em situações privadas, de preferência as de cunho familiar e doméstico; e a eleição de uma personagem mediana capaz de centralizar a ação.

São, pois, os pilares do romance histórico: a época representada, que coincide com um período de crise e mudança; e, acima da época, a presença de seres humanos que vivenciam, nas suas existências, mesmo quando deslocados dos grandes centros de poder, as consequências das alterações por que passa o período. Assim, não é preciso traduzir os grandes eventos, [...] básico é contar com a presença de individuos que plasmem o modo de ser, pensar e atuar nesses momentos determinantes, refletindo as tendências da época [...] (ZILBERMAN, 2003, p. 121).
Nesse contexto, a transição coletiva que mais profundamente afeta Sandro Lanari e o seu conflito e desenvolvimento como personagem é de ordem artística: no bojo da já citada Segunda Revolução Industrial, a rápida automatização e a alvorada do consumo de massa substituem os ofícios artesanais minuciosos (como a pintura) pelas inovações mecanizadas e de resultados cada vez mais próximos do instantâneo (como a fotografia), ou, na observação mais precisa de Carlos Reis, "uma decisiva mutação de procedimentos artísticos, na Segunda metade do século XIX, mutação determinada para consagração da fotografia como técnica e também como arte de representação de pessoas e coisas" (REIS, 2001, p. 9).

De inicio resistente ao ponto do desprezo - "[...] era mais uma prova do poder do retrato pintado sobre a fotografia. Só uma pintura reproduzia o interior da pessoa, só ela mexia com a profundidade humana, e só ela era verdadeiramente filosófica" (ASSIS BRASIL, 2002, p. 85) - e torturado pela memória do retrato feito por Nadar, Sandro se torna autor da "Foto do Destino", associa-se ao fotógrafo Carducci e familiariza-se progressivamente com os avanços da técnica até dominá-la: as novas emulsões, as câmaras cada vez menores, até portáteis, e o menor tempo de exposição - "são os modernismos", resigna-se Carducci, abanando a cabeça (ASSIS BRASIL, 2002, p. 150). Assim, passa a dedicar-se à fotografia com gosto, torna-se conhecido, respeitado, "quase rico", digno de menção elogiosa no Correio do Povo (ASSIS BRASIL, 2002, p. 160-161, 165). Nesse processo, obscurece-se o próprio limite entre uma e outra vocação:

A pedido dos clientes, também passou a fazer fotos que se pareciam a desenhos, águas-fortes, litografias. Bastava um pouco de técnica.

Ante esses resultados, Carducci comentou:

- Interessante. Você já notou uma coisa?

- O quê?

- Que seus retratos são quase quadros?

- Bobagem

- Mas são. Não percebe que, com isso, você volta a pintar? (ASSIS BRASIL, 2002, p. 154). 
Carlos Reis (2001, p. 9) vê nessa narrativa uma transcendência da história pessoal de Sandro Lanari para uma questão da representação, no momento crucial de emergência e afirmação da fotografia como técnica de fixação da imagem e como condição artística autônoma. O mesmo autor indica, ao analisar o episódio da "Foto do Destino", o êxito decisivo do meio fotográfico quando confrontado com a morte, "por reter nela o instante único e irrepetivel em que a vida e morte confinam. [...] O triunfo da fotografia feita arte é, à sua maneira, o triunfo da vida sobre a morte" (REIS, 2001, p. 9).

Em paralelo, a vida na província, que costumava causar estranhamento e quase repulsa, agora apraz Sandro, com as visitas a parques e ao teatro, o vento austral que "levava embora as nuvens, e viam-se abertas de azul" (ASSIS BRASIL, 2002, p. 170), os chinelos e o robe da manhã e as torradas "crocantes, gotejando manteiga no prato de porcelana" servidas da mesma maneira todos os dias (ASSIS BRASIL, 2002, p. 170). Na Itália, recorda com carinho seu cotidiano: "Fechou os olhos. Pensou em sua casa com varandas de ferro, pensou em seu estúdio bem-frequentado, pensou na dócil Violeta, nas filhas" (ASSIS BRASIL, 2002, p. 180).

Na conclusão de sua jornada, e depois de confrontar Nadar sem sucesso, Sandro chega à aceitação: e não apenas à aceitação de si mesmo e de sua arte, mas à aceitação de que não obterá, e quiçá sequer lhe cabe obter, as respostas definitivas pelas quais ansiava, e muito menos uma legitimação externa a conceder-lhe um status artístico hipotético e arbitrário. Cessa o desconsolo pela frustração do sonho um dia acalentado do que viria a ser sua vida e de quem ele mesmo viria a ser, pois a realidade não comporta cotejo com o plano volátil e intangivel dos ideais. $\mathrm{Na}$ juventude, o protagonista digladiava-se internamente entre o "eu" que entendia como verdadeiro e um "Outro" incompreensivel; na maturidade, compreende que a dicotomia inexiste, porque a desagregação vai além dela.

A cena na qual Sandro rasga em pedaços seu retrato e tranquilamente atira-os pela janela do trem expressa, na fragmentação literal da fotografia, a fragmentação do homem na era moderna com a qual Sandro finalmente se acostuma, destituida de certezas totalizantes, temperada pela efemeridade e pela multiplicidade. As últimas frases de $O$ pintor de retratos - que remetem à epígrafe do livro, de Montaigne: "Na verdade, o homem é de natureza pouco definida, extremamente desigual e variado. É dificil julgá-lo de maneira decidida e única" - constroem esse significado de maneira consistente e quase lírica:

De manhã, os meninos que jogavam bola às margens dos trilhos recolheram algumas frações avulsas da foto de Sandro Lanari. Levaram-nas a seu velho professor, de boné e cachimbo com fornilho de roseira, que estava sentado num banco da gare, aproveitando o último domingo antes do recomeço da escola. Ajudado pelas crianças, ele ensaiou uni-las sobre o assento do banco.

Após várias tentativas, disse:

- É o retrato de um homem, mas é impossivel formá-lo por inteiro. Faltam muitos pedaços, muitos... - Fez um gesto envolvendo toda a paisagem - devem estar por aí... - e com olhos de sábio, olhos que tanto viram e tanto amaram, percorreu a solidez terrestre dos campos e o devaneio infinito das nuvens (ASSIS BRASIL, 2002, p. 181).

Hanciau igualmente equivale esse instante à fragmentação da personagem e entende que "com isso chega-se ao cerne da preocupação do autor: o sentido da vida e a questão da ética aplicada ao cotidiano" (HANCIAU, 2006, p. 58). Nessa esteira, essa autora lê Sandro Lanari como menos pacificado eticamente ao final de sua trajetória, estabelecendo um paralelo com o olhar do estrangeiro colonizador a interpretar o Brasil e concluindo:

Embora ampliados os limites geográficos habituais da narrativa de Assis Brasil, além dos elementos externos ele aqui se fixa numa questão para muitos artistas e/ou intelectuais mais profunda: as tecnologias não são neutras: acima de tudo, são os homens (e as mulheres) que decidem sobre seu sentido e valor. Daí a frustração da perseguição utópica de Sandro Lanari. Ainda que como individuo possa ter sido um vencedor, seu arrivismo social impediu-o de entender a responsabilidade ética da arte (HANCIAU, 2006, p. 59).

Ainda mais crítica à condição de Sandro na idade madura é Alvarez (2011, p. 75), propondo que o fotógrafo se recusa em enfrentar sua verdade interior e, rumo à fragmentação de sua identidade. 
também liquefaz seus valores, posicionando a reflexão do velho professor na última cena como um lamento acerca do esvaziamento identitário do homem, sua destruição e dessubstancialização; "ele perde os valores que o humanizam, tanto na expressão de sua arte, quanto na relação com o Outro" (ALVAREZ, 2011, p. 75):

Destituido dos valores humanos, Lanari é a metonimia do burguês, fruto da sociedade capitalista, que entorpece sua consciência com transações financeiras e uma vida de fausto. $O$ sentimento de ser o centro do mundo justifica a prepotência de não aceitar as limitações que os críticos apontam em sua arte - quer de pintor, quer de fotógrafo -, legitima-lhe o seu autoritarismo de patriarca que aniquila Violeta. [...]

Consoante o ethos do narrador, o romance culmina com um desfecho trágico, construido pela reificação e diluição identitária do protagonista, e com o arremate do professor que entra na narrativa como um deus ex machina, assumindo a posição de um sábio diante de um aporismo - a irreparável existência de Lanari (ALVAREZ, 2011, p. 75).

O desfecho também sugere um comentário de ordem extraficcional, e é aí que chegamos a uma derradeira característica do novo romance histórico, extraída de Seymour Menton (1993, p. 43): a metaficção ou comentário do narrador sobre o processo de criação. Embora não sejam proferidos na voz de um narrador onisciente intruso, há indicios comparáveis às transformações da narrativa romanesca nos juizos encerrados no trecho acima e no seguinte diálogo entre Sandro e Carducci:

- [...] Cada vez mais as pessoas querem fotografar-se. O retrato pintado tornou-se caro. E no século do telégrafo e da locomotiva as pessoas têm pressa.

[...]

- Sim, as pessoas têm pressa, mas depois não se queixem. A fotografia apenas capta um instante do fotografado. Ficam impressas na chapa as dores de barriga, as brigas de ontem com as esposas e as queimações da bexiga. O retrato pintado, pela observação demorada que o pintor faz do caráter do retratado, só esse retrato reproduz toda a verdadeira psicologia do modelo. - Enfim lembrava-se dos juizos de René La Grande. E dissera o maior argumento de sua vida (ASSIS BRASIL, 2002 p. 70).

O pintor de retratos acompanha o processo de automação da virada do século XIX para o século
$X X$; é composto por seu autor na plena informatização da virada do século XX para o século XXI e, apesar de retomar "temas e acontecimentos que confirmam algumas das dominantes de sua já extensa obra ficcional" (REIS, 2001, p. 9), apresenta-se notadamente mais condensado, em extensão e configuração técnica, do que sua produção histórica até então (como Breviário das Terras do Brasil e a série Um Castelo no Pampa, para citar dois exemplos). Carlos Reis indica o episódio da "Foto do Destino" como sendo sintese "da reflexão meta-estética que nesta narrativa de Assis Brasil se encontra" (2001, p. 9).

A guinada criativa de Assis Brasil é comentada por José Castello (2001, p. 3), que identifica no romance as "sementes de uma nova estética, da contenção e da brevidade" depois de "25 anos em que prevaleceram o estilo barroco e o grande interesse pela história"; opõe "os amplos painéis históricos" que "vinham dando sinais de esgotamento" a "uma escrita mais introspectiva e tensa", "substantiva, de frases curtas e insubstituiveis, em que não se permite digressões ou reflexões, escrevendo apenas para empurrar a ação para a frente e para a frente". Castello (2001, p. 3) destaca os muitos acontecimentos embutidos em parágrafos curtos, bem como os elementos mínimos (frases cortantes, imagens fortes, ação acelerada) que compõem um ambiente narrativo "em que nada se desperdiça e no qual só a pulsação da vida parece contar". Ainda, o crítico ilumina o processo de escrita:

Em vez da escritura dispersa e caudalosa, ele opta agora pelo caminho mais estreito, mas também mais engenhoso, da concisão. O resultado não podia ser mais feliz. O pintor de retratos [...] é um livro talhado a golpes de faca, não só contido, mas preciso, em que cada palavra parece ocupar um espaço insubstituivel.

Depois de escrever as primeiras 40 páginas de O pintor de retratos, ainda no ano de 1998 . Assis Brasil entrou em crise. Insatisfeito com o próprio estilo, decidiu parar e meditar. Ficou quase seis meses sem escrever, em pânico, ruminando suas dúvidas, até que um dia pegou a primeira frase do livro anotado, que se estendia por longas seis linhas, e a resumiu assim:

"Embora os descaminhos futuros, Sandro Lanari nasceu pintor." Desse modo começa O pintor de retratos, um romance de frases 
breves e inexoráveis, do qual todos os excessos parecem excluidos (CASTELLO, 2001, p. 3).

Não se escapa, pois, ao pano de fundo metaficcional desses momentos cronológicos, seja no tocante à historiografia geral da literatura ou no âmbito da produção individual de seu autor, isto é, respectivamente: a crise do grande romance do século XIX em direção a novos formatos novelescos (e, pode-se perquirir, do próprio romance histórico para o novo romance mais enxuto, menos épico, mais psicológico); e a transição de Luiz Antonio de Assis Brasil enquanto ficcionista, descrita na entrevista concedida a José Pinheiro Torres:

JPT - Alguns críticos acham que o senhor pratica o romance histórico. Concorda com isso?

Assis Brasil - O romance histórico tradicional, ao estilo de Scott e Herculano, não se pratica mais; pelo menos, se pratica pouco - e de má qualidade. No denominado "novo romance histórico" - que Linda Hutcheon chama de "metaficção historiográfica" -, a história é sempre pretexto, e é deformada, reinterpretada, discutida e, até, criada. Imagino ter feito, e com certa freqüência, essa segunda modalidade, com recurso à paródia, ao pastiche e, uma ou duas vezes, ao plágio burlesco. Penso, contudo, que é um capítulo encerrado em meu trabalho. Hoje me preocupa, mais que tudo, a ficção. Mesmo que os plots estejam situados num tempo pretérito, isso é apenas uma opção do escritor: o passado me dá maior liberdade criadora, e as emoções e paixões me parecem mais autênticas (ASSIS BRASIL, 2001).

A teórica citada por Assis Brasil, Linda Hutcheon (1989, p. 3), trata da dança fronteiriça entre ficção e história, utilizando o termo "metaficção historiográfica" para obras que, como O pintor de retratos, por ai transitam:

O termo pós-modernismo deveria, quando usado em ficção, ser melhor reservado, por analogia, para descrever a ficção que seja a um tempo metaficcional e histórica em seus ecos dos textos e contextos do passado. A fim de fazer a distinção entre essa criatura paradoxal e a ficção histórica tradicional, eu gostaria de denominá-la "metaficção historiográfica". [...] A relação pós-moderna entre ficção e história é ainda mais complexa, feita de interação e de mútua implicação. A meta- ficção historiográfica trabalha para situar-se dentro do discurso histórico sem abdicar de sua autonomia enquanto ficção (HUTCHEON, 1989, p. 3-4, tradução nossa). ${ }^{2}$

À luz dessa entrevista, pergunta-se: os comentários de Sandro e Carducci sobre o estado da arte e as vontades dos retratados-consumidores, bem como a rendição final de Sandro à impermanência das formas e da vida, não falariam também da visão do autor sobre os estatutos artísticos em geral, sobre a evolução do gênero romance, especificamente o histórico, sobre um público leitor em transformação moldada ao menos em parte pela exposição às novas tecnologias, sobre as limitações da representação mimética do ser humano em toda sua complexidade, e, enfim, sobre sua criação ficcional particular, mormente no instante em que acometido pela "crise" relatada por José Castello (2001, p. 3)?

Reforça-se, por conseguinte, a classificação de O pintor de retratos nesse novo romance histórico, ou metaficção historiográfica, que, desafiando os limites entre um e outro discurso, realiza uma apropriação estética de matizes históricos e assim personaliza e humaniza a história, segundo Peter Burke (1997, p. 112-113):

\begin{abstract}
Se história e ficção parecem ser "gêneros borrados" hoje, deveriamos procurar explicações para esse borramento não apenas em termos de um vago espírito pós-moderno de nossa época, mas também em termos das preocupações internas de duas comunidades, "ficcionalistas" e historiadores. Do meu lado da cerca, parece claro que é o desejo de uma história com uma face humana, em reação contra a macro-história, a história quantitativa e o determinismo (seja marxista ou estruturalista), que atirou os historiadores nos braços dos romancistas. Por que os romancistas deveriam estar abraçando os historiadores nesse momento é uma questão que deixo para os críticos literários (BURKE, 1997, p. 114).
\end{abstract}

Ao revelar, por meio desses recursos, a verdade última alcançada por Sandro Lanari em sua alma, Luiz Antonio de Assis Brasil retrata o que de melhor a literatura pode fazer frente a

\footnotetext{
2 Do original: The term postmodernism, when used in fiction, should, by analogy, best be reserved to describe fiction that is at once metafictional and historical in its echoes of the texts and contexts of the past. In order to distinguish this paradoxical beast from traditional historical fiction, I would like to label it "historiographic metafiction." [... The postmodern relationship between fiction and history is an even more complex one of interaction and mutual implication. Historiographic metafiction works to situate itself within historical discourse without surrendering its autonomy as fiction.
} 
sempre parcial e insuficiente história oficializada. Retoma-se, como finalização, Antônio R. Esteves:

A literatura, enfim, trabalha o reino da ambiguidade. Suas verdades são sempre subjetivas: verdades pela metade, verdades relativas que nem sempre estão de acordo com a história. Nesse sentido, a recomposição do passado que a literatura faz é quase sempre falsa, se a julgamos em termos de objetividade histórica. Não há dúvidas de que a verdade literária é uma e a verdade histórica é outra. No entanto, embora recheada de mentiras - e talvez por isso mesmo - a literatura conta histórias que a história escrita pelos historiadores não sabe, ou não quer contar. Os exageros da literatura servem para expressar verdades profundas e inquietantes que só dessa forma poderiam vir à luz. Só a literatura - e poderiamos concluir assim as reflexões de Vargas Llosa no referido ensaio - dispõe das técnicas e poderes para destilar esse delicado elixir da vida: a verdade que se esconde nos corações humanos (ESTEVES, 2010, p. 20).

\section{Considerações finais}

O pintor de retratos, de Luiz Antonio de Assis Brasil, sustenta-se em uma historicidade de transição (refletida na transição da época de sua escrita) para delinear a jornada pessoal de seu protagonista; o compromisso ficcional sem dúvida se sobrepõe ao compromisso histórico e esse serve àquele na construção do enredo. Trata-se do novo romance histórico, releitura da narrativa historiográfica para o fim de reconstituí-la como arte narrativa, comportando, ainda, comentário metaficcional como seu elemento intrínseco.

Evidentemente, uma obra de tal qualidade autoriza exame sob as mais diversas óticas, inclusive no âmbito literário e histórico, os quais, como aqui estudado, entrelaçam-se na tênue configuração das fronteiras entre literatura e história; acreditamos ter cumprido o objetivo de contribuir um desses ângulos, e quiçá um meio adicional de apreciar a riqueza da narrativa.

Por fim, referimos que, embora a complexidade do romance e dos dispositivos nele utilizados mereçam ser esmiuçados com maior aprofundamento, o recorte aqui realizado faz-se necessário em face da extensão do formato a que nos propomos.

\section{Referências}

ALVAREZ, Aurora Gedra Ruiz. Uma imagem do homem, uma imagem da arte. In: PEREIRA, Helena Bonito Couto (org.). Novas leituras da ficção brasileira no século XXI. São Paulo: Editora da Universidade Presbiteriana Mackenzie, 2011. p. 51-77.

ASSIS BRASIL, Luiz Antonio de. [Entrevista cedida a] José Pinheiro Torres. São Paulo: 2001. Disponivel em: http://www.laab.com.br/vida.html. Acesso em: 08 dez. 2019.

ASSIS BRASIL, Luiz Antonio de. O pintor de retratos. 6 ed. Porto Alegre: L\&PM, 2002.

AUST, Hugo. O romance histórico e suas formas. Trad. Pedro Theobald. In: MELLO, Ana Lisboa de; MONTEIRO, Charles; MADARASZ, Norman Roland (org.). Literatura e história: encontros contemporâneos. Porto Alegre: Gradiva, 2016. p. 9-23.

BAUMGARTEN, Carlos Alexandre. O novo romance histórico brasileiro: o caso gaúcho. Letras de Hoje, Porto Alegre, v. 36, n. 2, p. 75-82, 2001. Disponivel em: http://revistaseletronicas.pucrs.br/ojs/index.php/fale/ article/view/14382/9565. Acesso em: o9 dez. 2019.

BURKE, Peter. As fronteiras instáveis entre história e ficção. In: GENEROS de fronteira: cruzamentos entre o histórico e o literário. São Paulo: Xamã, 1997. p. 107-115.

CASTELLO, José. O pintor de retratos. O Estado de São Paulo, São Paulo, 12 agosto 2001, Segundo Caderno, p. 3. Disponivel em: http://www.laab.com.br/referencias. html. Acesso em: 06 jun. 2020.

ESTEVES, Antônio R. O romance histórico brasileiro contemporâneo (1975-2000). São Paulo: Editora UNESP, 2010. https://doi.org/10.7476/9788539304479

HANCIAU, Nubia Jacques. Literatura e história em $O$ pintor de retratos, de Luiz Antonio de Assis Brasil. Cadernos Literários, Rio Grande, Editora da FURG, v. 12, p. 55-59, 2006. Disponivel em: http://repositorio.furg.br/ handle/1/2321. Acesso em: 06 jun. 2020.

HUTCHEON, Linda. Historiographic metafiction: parody and the intertextuality of history. In: O'DONNELL, Patrick; DAVIS, Robert Con (org.). Intertextuality and contemporary American fiction. Baltimore: Johns Hopkins University Press, 1989. p. 3-32. Disponivel em: https:// tspace.library.utoronto.ca/handle/1807/10252. Acesso em: 09 dez. 2019

LUKÁCS, Georg. O romance histórico. Trad. Rubens Enderle. São Paulo: Boitempo, 2011.

MENTON, Seymour. La nueva novela histórica de la América Latina, 1979-1992. Tradução livre. México: Fondo de Cultura Económica (FCE), 1993.

REIS, Carlos. O romance da fotografia. Jornal de Letras, Lisboa, p. 9, 12 dez. 2001. Disponivel em: http://www. laab.com.br/referencias.html. Acesso em: 06 jun. 2020.

ZILBERMAN, Regina. O romance histórico - teoria e prática. In: BORDINI, Maria da Glória (org.). Lukács e a literatura. Porto Alegre: EDIPUCRS, 2003. 


\section{Renata Fonseca Wolff}

Mestranda em Letras - Escrita Criativa na Escola de Humanidades da Pontificia Universidade Católica do Rio Grande do Sul (PUCRS), em Porto Alegre, RS, Brasil. Bolsista (Capes, Ministério da Educação). O presente trabalho foi realizado com apoio da Coordenação de Aperfeiçoamento de Pessoal de Nivel Superior - Brasil (Capes) - Código de Financiamento 001.

\section{Endereço para correspondência}

Renata Fonseca Wolff

Pontificia Universidade Católica do Rio Grande do Sul

Programa de Pós-Graduação em Letras

Av. Ipiranga, 6681, prédio 8, sala 403

Partenon, 97010082

Porto Alegre, RS, Brasil 